„Kwartalnik Filmowy” nr 113 (2021)

ISSN: 0452-9502 (Print) ISSN: 2719-2725 (Online)

https://doi.org/10.36744/kf.535

(c) Creative Commons BY-NC-ND 4.0

Piotr Zwierzchowski

Uniwersytet Kazimierza Wielkiego w Bydgoszczy

https://orcid.org/oooo-0002-1770-777X

\title{
Co się wydarzyło w Brighton
}

\section{Słowa kluczowe:}

Nowa

Historia Filmu;

Nowa Historia Kina;

zwrot historyczny

\begin{abstract}
Abstrakt
Michał Pabiś-Orzeszyna w książce Zwrot historyczny w badaniach filmoznawezych (2020) opisuje bardzo szczegółowo i precyzyjnie historie (w liczbie mnogiej) tytułowego zjawiska. Pokazuje towarzyszace mu inspiracje i metodologie, sytuuje je w różnych kontekstach, następnie poddaje wnikliwej krytyce, rekonstruując również spory między przedstawicielami - wydawałoby się - tego samego nurtu. Otrzymujemy nader kompetentny, starannie przemyślany przewodnik po Nowej Historii Kina/Nowej Historii Filmu, wdzierający się pod powierzchowne i unifikujące odczytania. Autor ma jednak większe ambicje niż tylko przedstawienie zwrotu historycznego w badaniach filmoznawczych. Jeśli przybliża czytelnikowi wspomniane spory o to, jak pisać o wczesnym kinie, czyni z tego punkt wyjścia do refleksji nad zagadnieniem bardziej fundamentalnym. Jego książka stanowi bowiem również głos w refleksji nad metodologią i samoświadomością humanistyki.
\end{abstract}




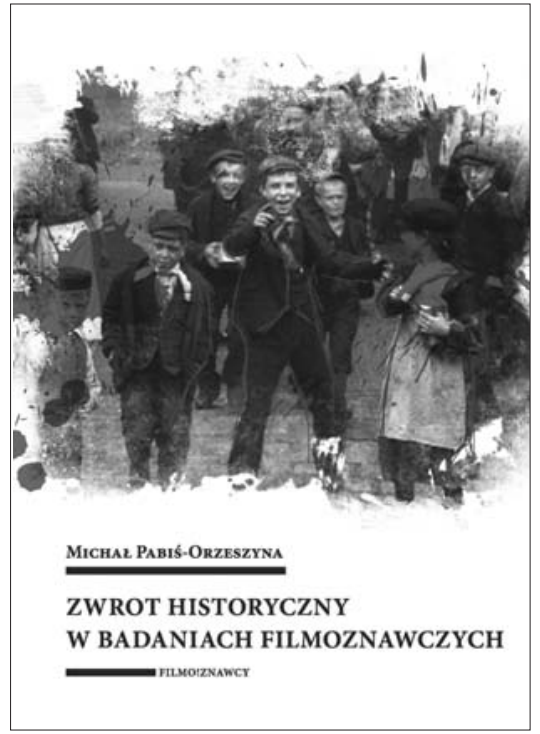

Zwrot stał się jedną z najważniejszych kategorii współczesnej humanistyki, ale z czasem - ze względu na jej nadużywanie, a jednocześnie inflację i stereotypizację znaczeniową - w dużej mierze zatracił wartość operacyjną ${ }^{1}$. Zresztą specyfika humanistyki nakazywałaby raczej, by dostrzec możliwość współwystępowania, przede wszystkim w środowisku akademickim, równoległych paradygmatów, choć wpływ instytucjonalizacji nauki na siłę ich oddziaływania sprawia, że nie jest to takie oczywiste. $W$ każdym razie pisanie historii poszczególnych zwrotów wymaga ostrożności, dystansu, a zwłaszcza namysłu metateoretycznego.

Tak właśnie czyni Michał Pabiś-Orzeszyna, skupiając swoją uwagę na zjawisku nazwanym - jak głosi tytuł omawianej książki - Zwrotem historycznym w badaniach filmoznawczych. Ma świadomość, że skoncentrowanie się na udowadnianiu zaistnienia tytułowego „zwrotu"2 - na przykład zgodnie z kryteriami opisanymi przez Doris Bachmann-Medick ${ }^{3}$ - może być zadaniem prowadzącym donikąd. Nie chodzi bowiem o nomenklaturę, ale rzeczywiste funkcjonowanie i oddziaływanie nowych koncepcji. Dlatego też deklaruje wprost: Intryguje mnie, w jaki sposób historycy kina definiuja swoja wtasna praktykę badawcza, w szczególności zaś chciałbym zanalizować relacje, w jakie historiograficzna samoświadomość oraz splecione z nia decyzje badawcze wchodza z materialna historia warunków wytwarzania wiedzy (s. 20).

Zmiany paradygmatów w nauce nie następują z dnia na dzień. Zwykło się jednak przyjmować bez zdziwienia, że w badaniach historycznofilmowych stało się to podczas konferencji Cinema 1900-1906, stanowiącej część 34. Kongresu Międzynarodowego Stowarzyszenia Archiwów Filmowych, zorganizowanego w maju 1978 r. w Brighton. Kongres ten, będący jednym z najbardziej znaczących i najczęściej przywoływanych wydarzeń w dziejach historiografii filmoznawczej, PabiśOrzeszyna w pewnym momencie nazywa osławionym (s. 29). Biorąc pod uwagę nadawaną mu rangę, można by uznać, że to swoisty lapsus. Lektura książki zdaje się jednak potwierdzać, że autor użył tego przymiotnika nieprzypadkowo.

Przejście od tradycyjnej historiografii do Nowej Historii Filmu/Nowej Historii Kina (słusznie Pabiś-Orzeszyna zwraca uwagę na niedookreśloność tego rozróżnienia) często jest traktowane jako osiągnięcie kolejnego etapu w progresywnie rozumianej metodologii historii filmu/kina. W tej perspektywie Brighton rzeczywiście stanowi swoisty mit założycielski, święty początek, od którego zaczęła się nowa era. Takie podejście zakłada, bo inaczej nie może, uogólnienie charakterystyczne dla mitycznego postrzegania czasu. Rzeczywistość jest jednak o wiele bardziej skomplikowana.

Podczas konferencji w Brighton udało się zrewidować wiele dotychczasowych opinii i przekonań związanych przede wszystkim z najwcześniejszymi dziejami kina. Stało się tak w dużej mierze dzięki wykorzystaniu licznych materiałów 
archiwalnych. Znaczenie konferencji było więc i tak niemałe, ale co ważniejsze zarysowane wówczas perspektywy zaczęły mieć olbrzymi wpływ na badania nad historią kina. Były jednak o wiele bardziej zróżnicowane, niż zakłada bardzo uproszczony, a jednocześnie najbardziej rozpowszechniany obraz zjawiska nazywanego Nową Historią Kina i/lub Nową Historią Filmu. Z drugiej strony, nie dla wszystkich hasło „Brighton” ma takie samo znaczenie.

Pabiś-Orzeszyna przypomina, że choćby w słynnej książce Roberta C. Allena i Douglasa Gomery'ego Film History: Theory and Practice - a także w innych znaczących pracach, jak we wprowadzeniach do tomów The New Film History: Sources, Methods, Approaches pod redakcją Jamesa Chapmana, Marka Glancy'ego i Sue Harper czy też Explorations in New Cinema History: Approaches and Case Studies pod redakcją Richarda Maltby'ego, Daniela Biltereysta i Philippe'a Meersa - w ogóle się ono nie pojawia. Tak naprawdę nie ma to wiele wspólnego z potencjalnym lub rzeczywistym znaczeniem wspomnianej konferencji, dużo więcej z instytucjonalnymi kręgami i wyborami, a zarazem sporami metodologicznymi prowadzonymi przez autorów.

Z drugiej strony chociażby sama historia pojęcia „kino atrakcji” dowodzi, że ślady tego nurtu badań, który pozornie zaczął się w Brighton, nietrudno odnaleźć już we wcześniejszych studiach i wydarzeniach (np. bibliotecznych czy muzealnych). Głównym celem rozważań Pabisia-Orzeszyny nie jest jednak przywoływanie kolejnych faktów i publikacji, ale historiograficzny namysł nad wytwarzaniem wiedzy o przeszłości, odrzucenie jej ahistoryczności. Teorie i książki filmoznawcze niekiedy zdają się wyrwane z czasu i przestrzeni. Zjawisko to w humanistyce jest niestety ciągle dość powszechne, tymczasem analiza szeroko rozumianych okoliczności powstania różnych koncepcji nie tylko przynosi korzyści historyczne, ale też pozwala na pełniejsze zrozumienie ich niuansów, związanych z nimi wyborów metodologicznych czy wreszcie ich obecności w instytucjach akademickich. Trudno więc nie zgodzić się z Michałem Pabisiem-Orzeszyną piszącym, że mało kogo - a szkoda - interesuja na przykład związki Noëla Carrolla z nowojorska awangarda filmowa lat 70. lub to, że Henri Bergson i Étienne-Jules Marey studiowali razem w Collège de France. Gdy zaś czytamy na temat "Od Caligariego do Hitlera", mało kto odnosi się do osób i instytucji, które Siegfried Kracauer zamieścił w "Podziękowaniach" $\left(\right.$ s. 22) ${ }^{4}$. Ponieważ dla autora podobne pytania mają znaczenie fundamentalne, nic dziwnego, że zadaje je w odniesieniu do Nowej Historii Kina, a że robi to precyzyjnie i ze znawstwem tematu, zyskujemy dostęp do dokładnie nakreślonej mapy tego nurtu, co więcej - ze znakomicie opracowaną legendą.

Autor wychodzi od rozważań poświęconych współczesnej humanistyce (choć już w tej części przywołuje nazwiska i poglądy filmoznawców), następnie koncentruje się na sposobach uprawiania historii historiografii filmowej, przyglądając się Nowej Historii Kina oraz Nowej Historii Filmu i szczególne znaczenie przypisując opozycji między kinofilską Fascynacją a naukową obojętnością, jak również zdecydowanym zwrotem ku empiryzmowi a odrzucającymi go ujęciami skłaniającymi się do silnej teorii. Później skupia się na postrzeganiu kina atrakcji jako kategorii badawczej. Zauważa, że koncept ten nie polegał na przywołaniu nowych filmów czy autorów, ale na uświadomieniu sobie "obcości” wczesnego kina. Nie chodzi bowiem jedynie o same źródła, ale także o pytania badawcze będące podstawą interpretacji wczesnego kina. Przypisując „kinu at- 
rakcji" wręcz rewolucyjną rolę w kształtowaniu badań nad wczesnym kinem, Pabiś-Orzeszyna wskazuje też na wątpliwości, jakie może budzić ujednolicający charakter tej interpretacji. Można to potraktować jako kolejny argument na rzecz koniecznej autorefleksji metodologicznej i ostrożności w (nad)używaniu popularnych pojęć. W czwartej części książki zwraca uwagę na wątpliwości związane z badaniami nad wczesnym kinem w kontekście tytułowego „zwrotu” i jego pochodnych, by w końcu wskazać na jego zdaniem najbardziej korzystne - także dla refleksji nad współczesnością i „nowymi” mediami - rozwiązania metodologiczne.

Michał Pabiś-Orzeszyna podjął się tematu niełatwego, również ze względu na konieczność uporządkowania rozległej materii. Nie tylko dobrze się wywiązał z tego zadania, ale z owego uporządkowania uczynił jedną z największych wartości swojej książki. Opisał bardzo szczegółowo i precyzyjnie historie (w liczbie mnogiej) tytułowego zjawiska. Pokazał towarzyszące mu inspiracje, metodologie oraz uwikłania i konflikty instytucjonalne, sytuując je w różnych kontekstach, a następnie poddał je wnikliwej krytyce. Autor nie opowiada się przy tym za poszczególnymi autorami, koncepcjami i rozwiązaniami. Interesuje go przede wszystkim rekonstrukcja i dekonstrukcja retoryki tych sporów. Odsłania napięcia między różnymi koncepcjami, pisze o sporach metodologicznych, czasem tak ostrych, że wydawałoby się - wykluczających możliwość zaliczenia poszczególnych autorów do tej samej formacji. Otrzymaliśmy zatem nader kompetentny, starannie przemyślany przewodnik po Nowej Historii Kina/Nowej Historii Filmu, wychodzący poza powierzchowne i unifikujące odczytania. Gdyby jednak Pabiś-Orzeszyna na tym poprzestał, zaprzeczyłby swojemu założeniu, zgodnie z którym wszelkie prace porządkujące jedynie to, co już napisane, bywają jałowe, prowadzą do ustatycznienia wiedzy, nierzadko też do jej nadmiernej hierarchiczności, stanowiącej naturalny, lecz groźny element praktyki naukowej.

W książce nacisk został położony na analizę badań nad wczesnym kinem, co w oczywisty sposób wynika z dużego zainteresowania filmoznawców związanych z Nową Historią Kina właśnie tym obszarem tematycznym. Nie chodzi jednak tylko o zakres tych studiów, poszczególne zagadnienia i opracowania czy wreszcie same zmiany w postrzeganiu tego kina. Namysł nad przewartościowaniami dominujących paradygmatów, przejściem od prac „historyków amatorów” (jak Georges Sadoul, Jean Mitry czy Jerzy Toeplitz) i progresywnego postrzegania sztuki filmowej jako dzieł „,wielkich mężów” i „,kamieni milowych” do empirycznej i racjonalistycznej refleksji nad przeszłością kina, spełniającej warunki profesjonalnej nauki (przynajmniej w odczuciu uprawiających ją osób), do wszechstronnej i wielokontekstowej analizy uwarunkowań kulturowych, społecznych, politycznych i ekonomicznych, stworzył szansę na metarefleksję historycznofilmową.

Michał Pabiś-Orzeszyna ma bowiem większe ambicje niż tylko przedstawienie tytułowego Zwrotu historycznego w badaniach filmoznawczych. Jeśli przybliża czytelnikowi wspomniane spory o to, jak pisać o wczesnym kinie, czyni z tego punkt wyjścia do refleksji nad zagadnieniem bardziej fundamentalnym. Jego książka dotyczy zwrotu historycznego w badaniach filmoznawczych, ale w gruncie rzeczy stanowi głos w debacie nad metodologią i samoświadomością humanistyki, także nad akademia, zależnościami i uwarunkowaniami decydującymi o instytucjonalnym funkcjonowaniu dyscyplin naukowych. Jest to o tyle istotne, 
że niektóre dyscypliny badawcze niezbyt chętnie podejmują namysł nad własną przeszłością i autorefleksją teoretyczną. Teza, że należy do nich filmoznawstwo, brzmi niestety dość przekonywająco.

Fundamentalne znaczenie ma w tym kontekście pojęcie i zarazem poczucie naukowości, będące przecież od lat jedną z najważniejszych przestrzeni sporu dotyczącego akademickiej profesjonalizacji i zarazem tożsamości chyba każdej dyscypliny. Do tego nawiązywało między innymi dążenie do nauki w pełni obiektywnej, niepoddającej się zewnętrznym oddziaływaniom, wolnej od wszelkiej kontekstualizacji. Taka chciała być też nowa historiografia filmoznawcza, co Pabiś-Orzeszyna pokazuje przede wszystkim na przykładzie jednej ze „świętych ksiąg" tego nurtu - Film History: Theory and Practice Roberta C. Allena i Douglasa Gomery'ego. Wiele polemik o charakterze metodologicznym, jak choćby spór o „sensacjonalizm” wczesnej kultury filmowej, toczyło się właśnie w odniesieniu do tożsamości filmoznawstwa jako dyscypliny naukowej.

Lektura książki uzmysławia metodologiczną różnorodność nurtu uważanego potocznie za jednolity. Pabiś-Orzeszyna pisze o tym przekonywająco, podając liczne dowody i osadzając je w rozmaitych kontekstach. Wskazuje na rozbieżności i nie tylko je porządkuje, przedstawiając przy tym własną propozycję wewnętrznych podziałów, ale też odsłania unifikacyjne dążenia humanistyki jako takiej. Tymczasem to analiza sprzeczności i zróżnicowania nadaje dynamikę badaniom historycznofilmowym. Bez niej Nowa Historia Kina stałaby się - przez odwołania do sposobów uprawiania wiedzy o przeszłości filmu, z którymi walczyła - historią arcydzieł i „wielkich mężów”, tworzących co prawda nie filmy, ale artykuły, książki i instytucje poświęcone ich badaniu. Oznaczałoby to kres badawczego niepokoju, hermeneutyki zdumienia, o którą apelował Thomas Elsaesser, a pod którym to apelem podpisuje się również Michał Pabiś-Orzeszyna.

Od dłuższego czasu także w polskim filmoznawstwie nie brakuje prac odwołujących się do założeń Nowej Historii Kina. Nie zawsze jednak tak uogólniające wyartykułowanie inspiracji metodologicznych rzeczywiście oddaje punkt wyjścia i perspektywę badawczą danego autora. Warto za każdym razem sprawdzić, czyje poglądy zostały przywołane: Toma Gunninga, Charlesa Mussera, a może Roberta C. Allena lub innych badaczy, jak również, czy stanowią one jedynie historycznofilmowy ornament, czy też przekładają się na pogłębioną świadomość metodologiczną. Nie chodzi bowiem tylko o sięganie do wybranych koncepcji lub - z drugiej strony - ich unikanie, ale odczytywanie instytucjonalnego uwikłania autorów i przyjmowania przez nich określonych strategii retorycznych. W przeciwnym razie odwołania do Nowej Historii Kina nie tylko nie pomoga w sprecyzowaniu dyskursu, ale wprowadzą do niego zamęt.

W Zwrocie historycznym w badaniach filmoznawczych niekiedy pojawia się sprzeczność, czy raczej nieostra granica, między badaczem rekonstruującym spory wokół i w ramach Nowej Historii Kina/Nowej Historii Filmu a autorem mającym określone przekonania metodologiczne, nieukrywającym swoich sympatii i antypatii. Tym bardziej interesujące dla czytelnika mogłoby być opisanie przez Pabisia-Orzeszynę jego własnych „uwikłań”, swojej biografii, geografii i historii, a zarazem miejsca w systemie produkcji wiedzy. Kieruję te słowa pod adresem nie tylko autora, ale także własnym. Zgadzam się bowiem całkowicie z wyartykułowanym w ostatnim zdaniu książki wezwaniem do pisania historii filmoznawców. 
Aby to jednak robić, trzeba - jak Filip Mosz w Amatorze - skierować obiektyw kamery najpierw na siebie.

Michał Pabiś-Orzeszyna, Zwrot historyczny w badaniach filmoznawczych, Państwowa Wyższa Szkoła Filmowa, Telewizyjna i Teatralna w Łodzi - Wydawnictwo Uniwersytetu Łódzkiego, Łódź 2020.

${ }^{1}$ Por. P. Abriszewska, Stereotyp zwrotu, inflacja przełomu we wspótczesnej humanistyce, w: "Zwroty" badawcze w humanistyce. Konteksty poznawcze, kulturowe i społeczno-instytucjonalne, red. J. Kowalewski, W. Piasek, Instytut Filozofii Uniwersytetu Warmińsko-Mazurskiego, Olsztyn 2010, zwłaszcza s. 57-59.

${ }^{2}$ Autor zachowuje dystans wobec wszelkich zwrotów, również tego, któremu się przygląda, zdając sobie sprawę, że łatwo przekroczyć granicę między wykorzystaniem tego pojęcia dla neutralnego opisu a użyciem go w funkcji nobilitującej jako oznaczenia postępu. Dlatego też podkreśla, że będzie konsekwentnie umieszczat ten termin w cudzysłowie (s. 20). Nie czyni tak jednak w tytule książki, a więc miejscu szczególnie znaczącym.

${ }^{3}$ D. Bachmann-Medick, Cultural Turns. Nowe kierunki w naukach o kulturze, tłum. K. Krzemieniowa, Oficyna Naukowa, Warszawa 2012.

${ }^{4}$ Pominięto odwołania do literatury.
Piotr Zwierzchowski
Profesor nauk humanistycznych, dyrektor Instytutu Nauk o Kulturze Uniwersytetu Kazimierza Wielkiego w Bydgoszczy, prezes Polskiego Towarzystwa Badań nad Filmem i Mediami. Zajmuje się przede wszystkim historią kina polskiego (zwłaszcza lat 1944-1989), ze szczególnym uwzględnieniem kontekstów decydujących o sensie przekazu filmowego. Autor monografii: Zapomniani bohaterowie. O bohaterach filmowych polskiego socrealizmu (200o), Piękny sen pedagoga. Literackie i filmowe portrety świata edukacji (2005), Pęknięty monolit. Konteksty polskiego kina socrealistycznego (2005), Spektakl i ideologia. Szkice o filmowych wyobrażeniach śmierci heroicznej (2006), Zezowate szczęście (2006), Kino nowej pamięci. Obraz II wojny śziatowej w kinie polskim lat 6o. (2013; Nagroda im. Bolesława Michałka za najlepszą filmową książkę roku), „Sasiedzi”. Film o bydgoskim ๗rześniu 1939 (2019; współaut. Mariusz Guzek); redaktor i współredaktor kilkunastu tomów zbiorowych, m.in.: Kino polskie wobec umierania i śmierci (2005), Kino polskie po roku 1989 (2007), Październik 1956 w literaturze i filmie (2010), Polskie kino popularne (2011), Kino polskie wobec II wojny światowej (2011), Polskie piśmiennictwo filmowe (2013), Kino, którego nie ma (2013), Konrad Eberhardt (2013), Polskie seriale telewizyjne (2014), Aleksander Fackiewicz (2015), ¿́ródła wizualne w badaniach nad historia kina polskiego (2018), Krzysztof Mętrak (2019), Rok 1968 - kultura, sztuka, polityka (2019), Maria Kornatoreska (2020), 1918 - kino polskie wobec odzyskania niepodlegtości (2020). 


\section{Bibliografia}

Abriszewska, P. (2010). Stereotyp zwrotu, inflacja przełomu we współczesnej humanistyce. W: J. Kowalewski, W. Piasek (red.), „Zwroty” badawcze w humanistyce. Konteksty poznawcze, kulturowe i społeczno-instytucjonalne. Olsztyn: Instytut Filozofii Uniwersytetu Warmińsko-Mazurskiego.

Bachmann-Medick, D. (2012). Cultural Turns. Nowe kierunki w naukach o kulturze (thum. K. Krzemieniowa). Warszawa: Oficyna Naukowa.

Pabiś-Orzeszyna, M. (2020). Zwrot historyczny w badaniach filmoznazczych. Łódź: Państwowa Wyższa Szkoła Filmowa, Telewizyjna i Teatralna w Łodzi - Wydawnictwo Uniwersytetu Łódzkiego.

\begin{tabular}{r|l} 
Keywords: & $\begin{array}{l}\text { Abstract } \\
\text { New Film History; }\end{array}$ \\
Piotr Zwierzchowski \\
What Happened in Brighton \\
History; & In the book Zwrot historyczny w badaniach filmoznawczych \\
historical turn & [The Historical Turn in Film Studies] (2020), Michał Pabiś- \\
& Orzeszyna precisely and in great detail describes the histo- \\
& ries (plural) of the title phenomenon. He shows the \\
& methodologies and inspirations accompanying it, places \\
& them in various contexts, and then subjects them to thor- \\
& ough criticism, also reconstructing disputes between rep- \\
& resentatives of the seemingly same trend. We have received \\
& a highly professional, carefully thought-out guidebook to \\
& the New Cinema History/New Film History, going beyond \\
& superficial and unifying readings. The author, however, has \\
& greater ambitions than just presenting the historical turn. \\
& If he makes the reader familiar with the above-mentioned \\
& disputes about how to write about early cinema, he also \\
& turns this into a starting point for reflecting on a more fun- \\
& damental issue. His book takes part in the discussion on the \\
& methodology and self-awareness of the humanities.
\end{tabular}

